I 567 , which varies from $5^{\frac{1}{2}}$ to $6 \frac{3}{4}$, is excessively red; $\pi^{1}$ Gruis is of a deep crimson, while its neighbour $\pi^{2}$ is conspicuously white; magnitudes respectively 6.7 and $5^{\circ} 9$. The star No. IOI63 of Oeltzen's Argelander is remarkable for its superb crimson colour; its place for 1875 is in R.A. 9 h. $45 \mathrm{~m}, 18 \mathrm{~s}$., N.P.D. I1 $2^{\circ} \mathbf{2 5 ^ { \prime }}$. $\mu$ Musca (5.3m.) is intense orange-red.

$\gamma$ Centauri, varying between $4^{\circ} 5$ and $5^{\circ} 1$, appears also to vary in colour, having been repeatedly noted as reddish, while at other times it was found without any marked tinge. N Velorum, which has a peculiar yellow colour, contrasting markedly with that of the numerous red stars in its vicinity, is suspected to vary in colour as well as in brightness, the period of the variations appearing to be not far from $4 \frac{1}{2}$ days, though the number of observations is not sufficient to give the law of the fluctuations. The positions of these stars for $1875^{\circ} \mathrm{O}$ are $; \gamma$ Centauri, R.A. 13h. 42m. 13s., N.P.D. $123^{\circ} 49^{\prime} 5 ; \mathrm{N}$ Velorum, R,A. 9 h. $27 \mathrm{~m}, 25$ s., N.P.D. $146^{\circ} 29^{\prime} \circ$

Dr. Gould says that there is "a decidedly greenish tinge to the light of $\beta$ Libræ, although its colour cannot properly be called conspicuous ;" this confirms Smyth's judgment on its tinge-pale emerald.

Telegraphic Determinations of Longitude - The Hydrographic Office at Washington has published a number of geographical positions determined in 1878 and 1879 by parties under the direction of Lieut,-Commanders F. M. Green and C. H. Davis of the United States Navy. The longitudes were fixed by telegraphic exchanges of time-signals, the initial point of measurement being the meridian of the Royal Observatory at Greenwich. The latitudes (with the exception of Lisbon, determined by the Dircctor of the Royal Observatory, Capt. F. A. Oom) result from numerous zenith-telescope observations of pairs of stars. The details of the observations are in the press, and will shortly appear; meanwhile we extract from No. 59 of the Notices of the IIydrographic Offece the positions of the more important points-

Lisbon-Centre of dome of the Royal Obscrvatory.

Lat. $3^{\circ} 42^{\prime} 3 \mathrm{I}^{\prime \prime} \cdot 3 \mathrm{~N}$. ... Long. oh. $36 \mathrm{~m} .44^{\circ} 68 \mathrm{~s}$. W.

Funchal (Madeira)-Flagstaff of Fort St. Jago.

Lat. $32^{\circ} 3^{8^{\prime}} 4^{\prime \prime} \times \mathrm{I}$ N. ... Long. Ih. $7 \mathrm{~m} .35^{\circ} 5^{6 \mathrm{~s}}, \mathrm{~W}$. Pernambuco $\rightarrow$ Lighthouse near Fort Ricão.

Lat. $8^{\circ} 3^{\prime} 22^{\prime \prime} \cdot 2 \mathrm{~S}$. ... Long. $2 \mathrm{~h}$. I9m, 27.775. W. Bahia-San Antonio Lighthouse.

Lat. $13^{\circ} \mathrm{O}^{\prime} 37^{\prime \prime} \cdot 4 \mathrm{~S}$. ... Long. $2 \mathrm{~h}, 34 \mathrm{~m}, 8 \cdot 37 \mathrm{~s}$. W.

Rio de Faneiro-Centre of dome of Imperial Observatory.

Lat. $22^{\circ} 54^{\prime} 23^{\prime \prime} \cdot 8 \mathrm{~S}$. ... Long, $2 \mathrm{~h}, 52 \mathrm{~m}, 4 \mathrm{I}^{\circ} 4 \mathrm{IS}$. W. Montevideo - Centre of south-east tower of Cathedral

Lat. $34^{\circ} 54^{\prime} 33^{\prime \prime} \circ \mathrm{S}$. ... Long. 3 h. $44 \mathrm{~m}$. $49^{\circ} \mathrm{O} 2 \mathrm{~s}$. W. Buenos Ayres-Centre of Cupola of Custom-house.

Lat. $34^{\circ} 36^{\prime} 29^{\prime \prime} \cdot 8$ S. $\ldots$ Long. 3 b. $53 \mathrm{~m} .28 \cdot 95^{\mathrm{s}}$. W.

FOUR-Figure LOGARITHMS AND ANTI-LOGARITHMS. Messrs. Layton, Fleet Street, have lately published tables of logarithms of numbers to four places from 1000 to 9999 , and anti-logarithms ${ }^{\circ} 0000$ to 9999 , arranged by General Hannyngton, similarly to the modern six and seven-figure tables. All the figures are printed, and the value sought is consequently found by mere inspection. The logarithms of numbers o to 999 would have required two more pages only, and probably would have been more used than any of the other pages. A complete manual of four-figure logarithms of numbers and trigonometrical functions is much to be desired, and would suffice for eclipses, occultations, star-corrections, and many subordinate astronomical calculations it is to be regretted that the logarithms of trigonometrical functions are not given in the present publication.

\section{ACTION OF PHOSPHORESCENT LIGHT ON} SELENIUM 1

A FEW weeks ago, when listening to Mr. Heaton's lecture on Balmain's Irminous paint at the Society of Arts, it occurred to me to try whether the faint light of phosphorescence would exercise any sensible effect upon the electric conductivity of selenium. I lately made some experiments in this direction, for which I adopted the following arrangement:-One of Dr. Werner Siemens' selenium preparations, of the lkind described by me in vol. vi, of the Society of Telegraph Engineers' Fournal, was placed in the circuit of two Daniell cells, together with a delicate Thomson's reflecting galvanometer. The sele-

\footnotetext{
I This article was sent to us by Dr. Obach in April last.-ED.
}

nium was put into one end of a lblackened brass tube, which was placed inside a dark box provided with a sliding door in front of the open end of the tube. The source of phosphorescence was a sheet of glass $20 \times 30$ centimetres, painted at the back with some phosphorescent material. ${ }^{1}$ This luminous sheet was placed before the opening of the box, usually at a distance of about $6 a$ centimetres from the selenium plate.

In the first series of experiments the phosphorescence of the sheet was excited by exposing it to light from different sources. The results were as follows:-

\begin{tabular}{|c|c|c|}
\hline $\begin{array}{l}\text { No. of } \\
\text { experi- } \\
\text { ment. }\end{array}$ & $\begin{array}{l}\text { Description of light used for exciting the } \\
\text { phosphorescence of the sheet. }\end{array}$ & $\begin{array}{l}\text { Increase of con- } \\
\text { ductivity of the } \\
\text { selenium by the } \\
\text { action of phos- } \\
\text { phorescent light. }\end{array}$ \\
\hline I & $\begin{array}{l}\text { The sheet was exposed to:- } \\
\text { Light reflected from ceiling of semi-dark } \\
\text { room for several minutes. }\end{array}$ & $\begin{array}{l}\text { Per cent. } \\
0^{\circ} 7\end{array}$ \\
\hline 2 & $\begin{array}{l}\text { Light reflected from ceiling of moderately } \\
\text { light room for fifteen minutes. }\end{array}$ & $2^{\circ} 4$ \\
\hline 3 & $\begin{array}{l}\text { Light of the sky at } 5 \mathrm{p} . \mathrm{m} \text {. for several } \\
\text { minutes. }\end{array}$ & $4^{\circ} 6$ \\
\hline 4 & $\begin{array}{l}\text { Light from a few inches of burning } \\
\text { magnesium ribbon. }\end{array}$ & $5^{\circ} \mathrm{I}$ \\
\hline 5 & $\begin{array}{l}\text { Sunlight for two minutes exactly. } \\
\text { Sunlight for five minutes exactly. }\end{array}$ & $\begin{array}{l}7 \cdot 8 \\
6 \cdot 3\end{array}$ \\
\hline
\end{tabular}

During these experiments the phosphorescent light acted on the selcnium immediately after the exposure of the sheet to light. After a lapse of some minutes the effect was found considerably lessened ; for instance, the third experiment gave only about $\frac{1}{6}$ th of the original value five minutes after the exposure. The sheet, exposed to strong light two hours" previously, showed no perceptible action on the selenium. The curious fact that the effect is less when the sheet is exposed to sunlight for five minutes than when it is exposed for only two minutes, is probably due to the circumstance that the sheet becomes sensibly warm during the longer period of exposure.

In the second series of experiments different lengths of magnesium ribbon were burnt in front of the sheet and at a distance of about 15 centimetres from it. The intensity of the phosphorescence increased with the time of exposure to light, as the following little table shows :-

\begin{tabular}{c|c|c}
\hline $\begin{array}{c}\text { Length of magnesium } \\
\text { ribbon. }\end{array}$ & $\begin{array}{c}\text { Time the magnesium } \\
\text { i was burning. }\end{array}$ & $\begin{array}{c}\text { Increase of conductivity } \\
\text { of selenium. }\end{array}$ \\
\hline Centimetres. & Seconds. & Per cent. \\
I & 2 & 0.8 \\
3 & 3 & 1.8 \\
IO & 5 & 2.4 \\
20 & I2 & 3.8 \\
30 & 21 & 3.4
\end{tabular}

In the third series of experiments a length of 20 centimetres of magnesium ribbon was burnt in front of the sheet at 20 centi. metres distance from it. The sheet was then, immediately after its exposure to light, placed at distances of $200, \mathbf{1 5 0}, 100$, and 50 centimetres respectively from the selenium. It was found that the effect upon the selenium varied approximately as the inverse distance of the sheet from the selenium plate, or in other words, as the square root of the light intensity. 'The same relation has been found by Dr. Werner Siemens and others for considerably stronger light intensities.

In the fourth series of experiments the phosphorescent light was made to pass through differently-coloured sheets of glass before acting on the selenium. It was found that colourless glass transmitted all the active rays. Blue glass transmitted $\frac{6}{7}$ ths of the total amount; green glass transmitted $\frac{1}{7}$ th; red (almost monochromatic); and yellow glass transmitted no perceptible action.

In the fifth series of experiments the action of the sheet upon the selenium was compared with that of a spermaceti candle, the phosphorescence of the sheet being excited by diffused day. light. Two separate sets of measurements with the standard x.A so-called Aladdin's lamp from Messrs. Ihiee and Horne, London.' 
candle at different distances ( $2 \frac{1}{2}$ and $3 \frac{1}{2}$ metres) from the selenium gave tolerably concordant results when calculated on the supposition that the effect upon the selenium varies as the square root of the light intensity. The influence of about $35^{\circ}$ square centimetres of the luminous sheet on the selenium was found equal to that of 0.0014 standard candle, or 0.04 standard candle per square metre.

In conclusion I wish to remark that the above must be considered only as preliminary experiments, and the figures given as only approximate. I am now engaged in making further experiments on this subject with the endeavour to obtain more accurate results and to extend these researches, as it seems probable that the sensitive selenium plate may render similar services to the study of phosphorescent light as the thermopile has rendered to the study of radiant heat. EUGEN OBACH

\section{AGRICULTURAL CHEMISTRY ${ }^{1}$}

II.

$\mathrm{I}^{\mathrm{T}}$ has been shown that the plant may receive abundance of nitrogen, may produce abundance of chlorophyll, and may be subject to the influence of sufficient light, and yet not assimilate a due amount of carbon. On the other hand, it has been seen that the mineral constituents may be liberally provided, and yet, in the absence of a sufficient supply of nitrogen in an available condition, the deficiency in the assimilation of carbon will be still greater. In fact, assuming all the other necessary conditions to be provided, it was seen that the amount of carbon assimilated depended on the available supply of nitrogen.

In a certain general sense it may be said that the success of the cultivator may be measured by the amount of carbon he succeeds in accumulating in his crops. And as, other conditions being provided, the amount of carbon assimilated depends on the supply of nitrogen in an available form within the reach of the plants, it is obvious that the question of the sources of the nitrogen of vegetation is one of first importance. Are they the same for all descriptions of plants? Are they to be sought entirely in the soil, or entirely in the atmosphere, or partly in the one and partly in the other?

These are questions which $\mathrm{Mr}$. Lawes and myself have dis. cussed so frequently that it might seem some apology was due for recurring to the subject here, especially as I considered it in some of its aspects before this Section at the Sheffield meeting last year. But the subject still remains one of first importance to agriculture, and it could not be omitted from consideration in such a review as I have undertaken to give. Moreover, there are some points connected with it still unsettled, and some still disputed.

It will be remembered that De Saussure's conclusion was that plants did not assimilate the free or uncombined nitrogen of the atmosphere, and that they derived their nitrogen from the compounds of it existing in the atmosphere, and especially in the soil. Liebig, too, concluded that plants do not assimilate nitrogen from the store of it existing in the free or uncombined state, but that ammonia was their main source, and he assumed the amount of it annually coming down in rain to be much more than we now know to be the case.

Referring to our previous papers for full details respecting most of the points in question, I will state, as briefly as I can, the main facts known-first in regard to the amount of the measurable, or as yet measured, annual deposition of combined nitrogen from the atmosphere; and secondly as to the amount of nitrogen annually assimilated over a given area by different crops-so that some judgment may be formed as to whether the measured atmospheric sources are sufficient for the requirements of agricultural production, or whether, or where we must look for other supplies?

First, as to the amount of combined nitrogen coming down as ammonia and nitric acid in the measured aqueous deposits from the atmosphere.

Judging from the results of determinations made many years ago, partly by Mr. Way, and partly by ourselves, in the rain, \&c., collected at Rothamsted; from the results of numerous determinations made much more recently by Prof. Frankland in the deposits collected at Rothamsted, and also in rain collected elsewhere; from the results obtained by Boussingault in Alsace; from those of Marié-Davy at the Meteorological Observatory at

I Opening Address in Section B (Chemical Science), at the Swansea meeting of the British Association, by J. H. Gilbert, Ph.D., F.R.S.,
Montsouris, Paris; and from those of many others made in France and Germany-we concluded, some years ago, that the amount of combined nitrogen annually so coming down from the atmosphere would not exceed 8 or ro lbs. per acre per annum in the open country in Western Europe. Subsequent records would lead to the conclusion that this estimate is more probably too high than too low. And here it may be mentioned in passing, that numerous determinations of the nitric acid in the drainage water collected from land at Rothamsted, which had been many years unmanured, indicate that there may be a considerable annual loss by the soil in that way; indeed, probably sometimes much more than the amount estimated to be annually available from the measured aqueous deposits from the atmosphere.

It should be observed, however, that the amount of combined nitrogen, especially of ammonia, is very much greater in a given volume of the minor aqueous deposits than it is in rain; and there can be no doubt that there would be more deposited within the pores of a given area of soil than on an equal area of the non-porous even surface of a rain-gauge. How much, however, might thus be available beyond that determined in the collected and measured aqueous deposits, the existing evidence does not afford the means of estimating with any certainty.

The next point to consider is-What is the amount of nitrogen annually obtained over a given area, in different crops, when they are grown without any supply of it in manure? The field experiments at Rothamsted supply important data relating to this subject.

Thus, over a period of 32 years (up to 1875 inclusive), wheat yielded an average of $20.7 \mathrm{lbs}$. of nitrogen per acre per annum, without any manure; but the annual yield has declined from an average of more than $25 \mathrm{lbs}$. over the first 8 , to less than $16 \mathrm{lbs}$. over the last $\mathbf{1 2}$, of those 32 years; and the yield (it is true with several bad seasons) has been still less since.

Over a period of 24 years barley yielded 18.3 lbs. of nitrogen per acre per annum, without any manure; with a decline from 22 lbs. over the first twelve, to only $14^{\circ} 6$ lbs. over the next 12 years.

With neither wheat nor barley did a complex mineral manure at all materially increase the yield of nitrogen in the crops.

A succession of so-called "root-crops"-common turnips, Swedish turnips, and sugar-beet (with 3 years of barley intervening after the first 8 years) -yielded, with a complex mineral manure, an average of $26.8 \mathrm{lbs}$. of nitrogen per acre per annum over a period of $3^{\mathrm{I}}$ years. The yield declined from an average of 42 lbs. over the first eight years, to only I $3 . \mathrm{r}$ lbs. (in sugarbeet) over the last 5 of the 3 I years ; but it has risen somewhat during the subsequent 4 years, with a change of crop to mangolds.

With the leguminous crop, beans, there was obtained, over a period of 24 years, $3 \mathrm{I}^{*} 3 \mathrm{lbs}$. of nitrogen per acre per annum without any manure, and $45^{\circ} 5 \mathrm{lbs}$. with a complex mineral manure, including potass (but without nitrogen). Without manure the yield declined from $48 \cdot 1$ lbs. over the first 12 years to only $14^{\circ} 6 \mathrm{Ibs}$. over the last 12 ; and with the complex minera manure it declined from $6 \mathrm{I}^{\circ} 5$ lbs. over the first $\mathbf{I} 2$, to $29^{\circ} 5 \mathrm{lbs}$. over the last 12, years of the 24 .

Again, an ordinary rotation of crops of turnips, barley, clover, or beans, and wheat, gave, over a period of 28 years, an average of $36.8 \mathrm{lbs}$. of nitrogen per acre per annum without any manure, and of $45^{\circ} \mathrm{lbs}$. with superphosphate of lime alone, applied once every four years, that is for the root crop. Both without manure, and with superphosphate of lime alone, there was a considerable decline in the later courses.

A very remarkable instance of nitrogen yield is the follow ing-in which the results obtained when barley succeeds barley that is when one gramineous crop succeeds another, are con trasted with those when a leguminous crop, clover, intervenes between the two cereal crops. Thus, after the growth of six grain crops in succession by artificial manures alone, the field so treated was divided, and, in 1873 , on one half barley, and on the other half clover, was grown. The barley yielded $37^{\circ} 3 \mathrm{lbs}$. of nitrogen per acre, but the three cuttings of clover yielded $15^{\circ} 3$ Ibs. In the next year, 1874, barley succeeded on both the barley and the clover portions of the field. Where barley had previously been grown, and had yielded $37.3 \mathrm{lbs}$. of nitrogen per acre, it now yielded $39 . \mathrm{I}$ lbs. ; but where the clover had previously been grown, and had yielded $\mathrm{I}_{5} \mathrm{I}^{\circ} 3 \mathrm{lbs}$. of nitrogen, the barley succeeding it gave $69^{\circ} 4 \mathrm{lbs}$, , or $30^{\circ} 3 \mathrm{lbs}$. more after the removal of $\mathrm{I}_{5} \mathrm{I}^{\circ} \mathrm{Ibs}$. in clover, than after the removal of only $37.3 \mathrm{lbs}$. in barley. 